\title{
my mother brings: ma mère rassemble un groupe de petites filles
}

\author{
Carole Thorpe
}

\begin{abstract}
Dans "my mother brings: ma mère rassemble un groupe de petites filles," Carole Thorpe présente un monde composé de deux voix, de deux langues tant dans le sujet que dans la structure même de la nouvelle. Sa langue maternelle est l'anglais, la langue qu'elle parle et comprend facilement, cette langue qu'elle peut manipuler, nuancer. Toutefois, cette langue maternelle n'est pas vraiment la langue de sa mère. L'autre langue est le français; cette deuxième langue est celle que sa mère tente de lui apprendre, la langue de la cuisine où sa mère travaille, la langue de sa grandmère, la langue faite de petits mots solides. La cuisine devient un centre où les mots français peuvent prendre vie. Cet univers laisse libre-cours à la petite et la narratrice, et comme nous avise son petit livre La cuisine est un jeu d'enfants: "Les enfants et les poètes aiment 'désobéir."
\end{abstract}

I.

My mother brings together a circle of small girls. To speak French, all about six years old. We gather round. A man from France, Phillippe, has brought back an African doll from the Belgian Congo. We learn, la poupée, les yeux, les lèvres, les cheveux. Later, Phillippe gives me a book, La Cuisine est un jeu d'enfants. I read, Lavez-vous toujours les mains. Les enfants et les poètes aiment "désobeir."

I turn my hearing aid on. Now I hear birds, crickets, alarm clocks. Je suis dured'oreille. Jen'entends pas les sons aigus. My mother anxiously asks the pediatrician, why can't she speak yet. She gets mad at him, he doesn't think this is a problem. I turn my hearing aid up a fraction, strain to hear French. What is French? Is it more poetic to make a mistake? Si vous êtes méchants, désobéissez et devenez bons.

When my mother was a child, she learned French from The Nuns at St. Patrice de Beaurivage, south of Quebec City. Quand ma mère était petite 
fille, elle a appris français chez les Soeurs à St. Patrice de Beaurivage, au sud de Québec. Summers she stayed here with her grandmother, Mary Simpson Ross. Where my great-grandmother was the head of the Ross seigneury at St. Patrice de Beaurivage until 1936. Mon arrière-grandmère était écossaise mais elle parlait français. When I was a child, I wanted to speak French. Imagine speaking French in Calgary, with bagpipes and cowboys, Gaelic, Blackfoot and Cree. Quand j'étais petite fille, je voulais parler français à l'école.

Mes pensées vont très vite en anglais; mes pensées sont peu connues. Si vous mangez vos ongles désobéissez et mangez la bonne cuisine. Je suis francophile; ma mère est anglophone qui parle français aux voisines. Deciphering a letter written by your great-grandmother (summers at Beaurivage, she read in English to your mother, but spoke French in the villages of the Ross seigneury). Wishing the language would leave you alone because headlines, television, advertising assault you. You have no choice but to retreat - and read a book. Or write. Before you open the door, to speak English or French.

Because of the assault, your eyes are bruised, your mother tongue relentlessly assails you. A second language becomes more fragile. You can be hard in your mother tongue; you know the precise turning of words. Know you can spar or retreat. I read a French word, hear it suspended by a francophone who pronounces it effortlessly. Like a small bird, I mispronounce a French word, a sound caught between English and French. French with an English accent, embarrassed - not the mother tongue, but the motherless tongue. The mother tongue of others who mother you; francophone men and women mothertongue you. Here you are in your second tongue, motherless. Je suis anglophone; je parle anglais rapidement et aisément.

When I was a child, I would carry very large books. I was small, and I impressed teachers and students. In elementary school, I pretended that I could hardly carry these magnificent books. I pretended that I had so much reading to do, so much work. But often I didn't read these books. Instead, I made up fantastic stories about birds. Women and children inhabit the third world in literature. C'était curieux comment je voulais parler français mais les institutions étaient très anglaises. Les grands livres anglais étaient comme des talismans. 
II.

If you could hear everything you might want earmuffs. Too much noise, not enough language. Whose language? Now I hear more than I used to; I am hard of hearing. Je suis dure d'oreille, je porte un appareil auditif. What is missing is subtle. What did you say? C'est un problème subtile. Écoutez bien, on parle deux langues ici. One language for each ear. Two languages for both ears. The mode of speaking requires the appropriate mode of listening; the physical capacity to hear is a gift.

En français, je cherche des petits mots et des petits dictionnaires. Ces petits mots sont solides et je ne les oublie pas. Je suis anglophone. J'habite le Tiers Monde dans la littérature anglaise. I can carry small French words in my knapsack. I have to lose my hometown and several librairies in order to discard my English vocabulary. I can get rid of more English words by having a garage sale; magazines, books and newspapers are recaptured by strangers. Je garde les livres français. Je copie des mots français dans un petit cahier. Les mots français sont extraordinaires et deviennent plus grands que les mots anglais. Mettez toujours un tablier. Laissez toujours la cuisine propre. I always wear an apron. I always keep my kitchen clean.

Ma mère rassemble un groupe de petites filles. Pour parler français, à peu près six ans. Nous nous rencontrons, nous faisons un cercle. Un français, Phillippe, a apporté une poupée africaine du Congo Belge. Nous apprenons, la poupée, les yeux, les lèvres, les cheveux. Plus tard, Phillippe me donne un livre, La Cuisine est un jeu d'enfants. Je lis, Lavezvous toujours les mains. Les enfants et les poètes aiment "désobéir."

J'allume mon appareil auditif. Maintenant j'entends les oiseaux, les grillons, les réveils. Je n'entends pas les sons aigus. Ma mère demande anxieusement au pédiatre: "Pourqoui elle ne parle pas encore?" Elle est fâchée contre lui; il croit que ce n'est pas un problème. Je monte mon appareil auditif un tout petit peu, je tends l'oreille pour entendre le français. Qu'est-ce que c'est le français? Est-ce plus poétique de se tromper? Si vous êtes méchants, désobéissez et devenez bons.

I begin to name my universe. When I look up, I notice that there are satellites and space shuttles. J'imagine que je suis francophone. J'aide ma 
mère à faire la cuisine. Je prends un oeuf du réfrigérateur; je le casse dans un petit bol que ma mère a pris dans l'armoire. Je regarde un satellite dans le ciel; je remarque comment un cafard s'approche de mes pieds. In French, sounds disappear so quickly as I speak that I become frightened. I am afraid that all this work will be wasted because all the manuals here are in English. Je commence à renommer l'univers. Je casse un petit oeuf dans un petit bol. Mais ce n'est pas mon universe - I speak English maternally (this is an egg, this is a bowl).

III.

Look - I've found a French-English dictionary on this dusty basement shelf. I don't know how to say egg in French. But I can see - un oeuf, le petit oeuf. Now I break an egg into a small bowl that my mother takes from the cupboard. My mother is an excellent cook and I am afraid that I will never be able to cook as well as her. She whisks something I can't see out of the cupboard. On peut trouver un oeuf dans ce petit dictionnaire. Un oeuf n'est pas dans le réfrigérateur, c'est dans le dictionnaire français-anglais. On peut découvrir des oeufs vivants ou se trouvent des thèmes spectaculaires. Les-voici: oeufs frais du jour; oeufs durs, cuits dans leur coquille jusqu'à ce que les blancs et les jaunes soient durs. Can you find a broken egg in the dictionary? Je cherche un oeuf dur, arrondi, turquoise dans les deux langues.

I am looking for a small round turquoise egg. When I was a child, I wanted to be an ornithologist. Je voulais être ornithologiste. I was presented with a very large book for general proficiency in grade three. In this book, Birds of America, I studied charts of different colored eggs. Are there any charts that show the insides of eggs? Do all eggs have whites and yellows? I designed scrapbooks about birds and won prizes for the scrapbooks. People treated me royally and gave me bird books; adult discussions were changed to the subject of birds. I was a minor celebrity.

Je voulais être ornithologiste mais je suis restée chez moi. Je devais aider ma mère à faire la cuisine. In my first scrapbook on birds, I wrote: "I suppose you think the robin is brownish on his feathers and red on his breast. That is true, but he has many other colors." Je suppose vous 
pensez que le Merle d'Amérique a des plumes bruns et la gorge rouge. $C^{\prime}$ 'est vrai, mais il a plusieurs d'autres couleurs. I turn my hearing aid on. Now I hear robins and sparrows. Dans mes deux mains, je tiens un très petit oeuf. Je l'ai trouvée dans un nid et ma mère n'a pas remarqué ce petit nid. My mother was so busy cooking that she didn't notice anything outside the window.

These small words in French startle me. The words arrive suddenly, fly away rapidly. I try to call back the words. When I see them in the distance, they are free. When I tug the words close, they are tattered. Words break free from my hands, land silently on the table. I touch the table with its papery words and the words fly away. Regardez toujours comment vous cassez un oeuf dur, arrondi, turquoise dans un petit bol. Regardez les paroles: elles se perchent sur mes lèvres. The small French words perch on my lips when I call them. I am almost their mother.

Je découvre comment je suis taciturne. Je prends mes paroles et je les mets sur une table. Je suis taciturne, têtue. Je touche la table et les paroles $s^{\prime}$ envolent. Ces petites paroles en français me surprennent. Les paroles arrivent soudainement et $\mathrm{s}^{\prime}$ envolent rapidement. Je dois rappeler les paroles. Quand on les voit au loin, elles sont très libres. Quand on tire les paroles à soi, elles sont déchirantes.

Maintenant, je suis travailleuse. Je fais de la recherche scientifique, je suis au travail. Les oiseaux écoutent comment j'étudie français. C'est mon métier; je regarde les mots français avec mes jumelles. Les petits mots s'envolent. Je suis maladroite dans cette belle langue. Mes travaux vont très bien. My mother is tired of housework; she decides to change professions. I remember my mother but she has gone away to take a job as a field naturalist. It is easier to forget her when she is occupied and observant. She travels around the world and sends postcards of birds: yellow-crowned night heron, scarlet ibis, white-crowned sparrow.

At last, I can't remember my mother and I don't know if she remembers me. She works hard at her new job and in order to concentrate, she has to forget that she has a daughter. I remember a few English words and then I forget them. Je fais les travaux ménagers, je commence à travailler. J'entends: Faucon pèlerin, Bihoreau à couronne noire, Canard arlequin, Petit Garrot, Balbuzard, Grue du Canada, Harfang des neiges. Ma mère 
est naturaliste; elle regard souvent des oiseaux, des animaux, des fleurs. Enfin - je suis poète, je cherche ma mère française.

\section{Works Cited and Notes}

All italicized quotes are from La Cuisine est un jeu d'enfants by Michel Oliver, published by Random House, New York (1963); translated and adapted by Charlotte Turgeon; preface by Jean Cocteau. Le Micro-Robert Poche, published in Montreal (1992) by Dicorobert, influenced "les oeufs." Aritha van Herk, in "An(Other) Third World: Girls in Children's Literature," elucidates how girls are damaged by children's literature in her collection of essays, The Frozen Tongue, published by Dangaroo Press (New South Wales, Australia:1992). She discusses how women and children are part of the "Third World" in literature. The essay influenced some of the writing and particularly triggered my memory of the "big book performance" in section I.

\section{Remerciements}

Premièrement, je veux remercier ma mère, Cecilia Anne Roy Thorpe. Je veux remercier Odile Rollin et Eileen Lohka aux Département de français, d'espagnol et d'italien de l'Université de Calgary, Calgary, Alberta. Aussi, je veux remercier mon frère, Ken Thorpe, pour une liste des oiseaux de Montréal. Cette liste des oiseaux était préparée par La Société québécoise de protection des oiseaux (The Province of Quebec Society for the Protection of Birds). 